
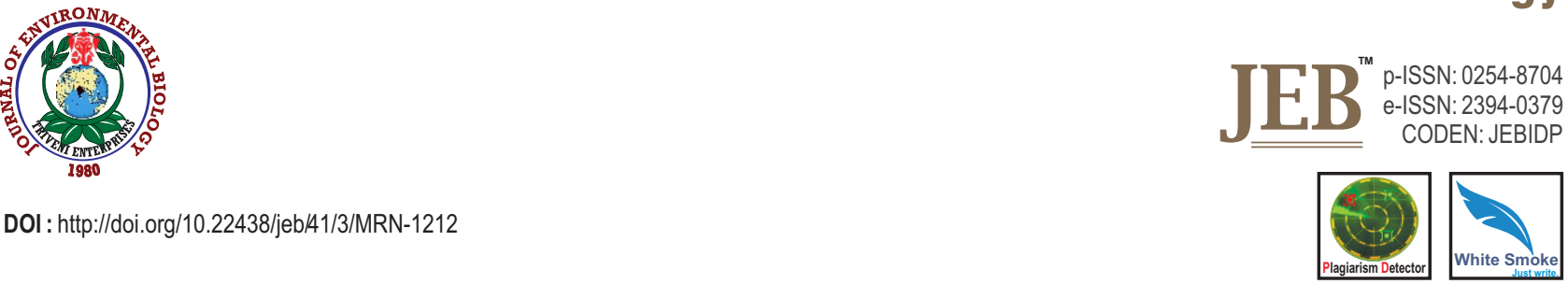

\title{
Potential of microbial inoculum from buffalo feces in activating lignite coal bed methane
}

\author{
E.T. Marlina ${ }^{1 *}$, H. Hamdani', R. Ridwan ${ }^{3}$, L. Ikhsani', Y.A. Hidayati', K.N. Rahmah ${ }^{1}$ and E. Harlia \\ ${ }^{1}$ Faculty of Animal Husbandry, Universitas Padjadjaran, Sumedang-45363, Indonesia \\ ${ }^{2}$ Faculty of Geological Engineering, Universitas Padjadjaran, Sumedang-45363, Indonesia \\ ${ }^{3}$ Research Center for Biotechnology, Indonesian Institute of Sciences, Cibinong-16911, Indonesia \\ *Corresponding Author Email : eulis.tanti@unpad.ac.id
}

\section{Abstract}

Aim: This research aimed to study the ability of microbial consortium from buffalo feces to produce coal bed methane (CBM) in lignite coal through invitro technique.

Methodology: This study was carried out in 2 stages: In first stage, microbes activated using in-vitro technique, and at second stage volatile fatty acids (VFA) and coal bed methane production were estimated. The nutrition source for inoculum activation was of three types: $100 \%$ concentrate: $70 \%$ concentrate: $30 \%$ grass and $30 \%$ concentrate: $70 \%$ grass. Biogas digester in laboratory-scale utilized $100 \mathrm{ml}$ serum bottle filled with $70 \mathrm{ml}, 98-5$ media and $7 \mathrm{~g}$ coal. Microbial inoculum was inoculated on digester using a $10 \mathrm{ml}$ syringe and incubated at $39^{\circ} \mathrm{C}$. Parameters observed to measure the quality of inoculum were total number of anaerobic microbes, kinetics, and biogas production during fermentation. Complete Randomized Design with two factorial consisted of incubation period as factorAand inoculum dosages as factor $B$.

Results: The activation process of inoculum from buffalo feces was required to produce coal bed methane in anaerobic digestion. During activation process, the microbes from buffalo feces in a mixture of $70 \%$

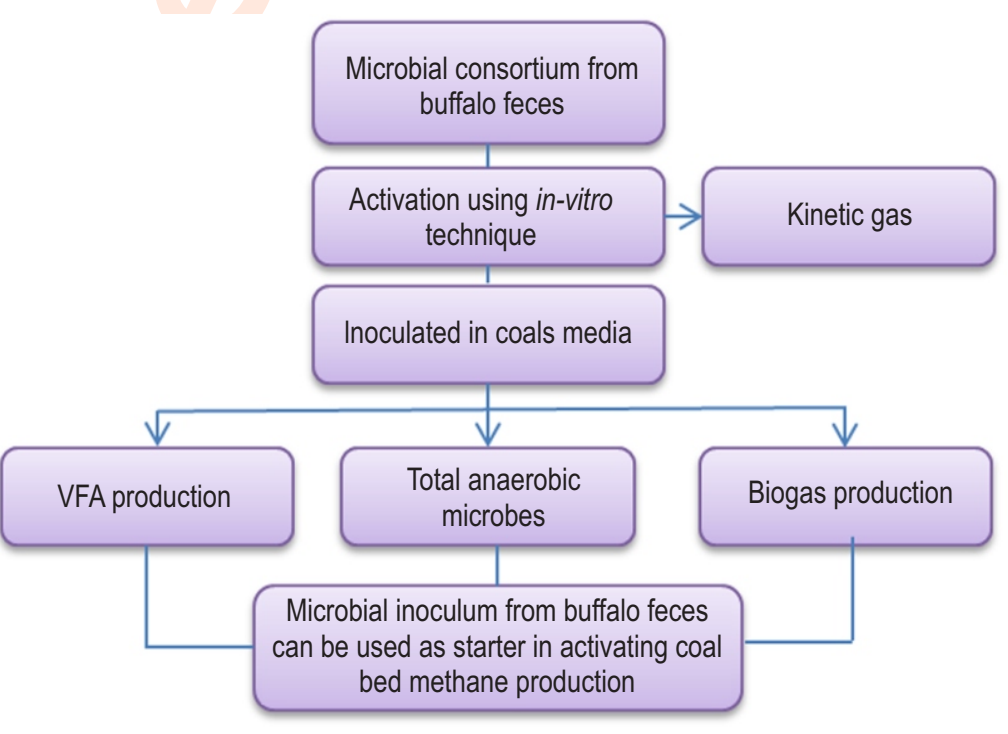
concentrate and $30 \%$ grass at $48 \mathrm{hr}$ observation could produce total gas approximately $22.5 \mathrm{ml}$ at $48 \mathrm{hr}$ observation. Addition of activated buffalo feces anaerobic inoculum on the anaerobic digestion as much as $6 \%$ produced the highest number of anaerobic bacteria, and VFAaccounted for $31 \times 10^{10} \mathrm{CFU}$ $\mathrm{ml}^{-1}$ and $171.7 \mathrm{mM}$, respectively. Meanwhile, the highest methane production reached $128.61 \mathrm{ml}$ on adding $6 \%$ inoculum.

Interpretation: Microbial inoculum from buffalo feces can be used for producing lignite coal bed methane.

Key words: Buffalo feces, Coal bed methane, Microbial inoculum, Volatile fatty acids

How to cite : Marlina, E.T., H. Hamdani, R. Ridwan, L. Ikhsani, Y.A. Hidayati, K.N. Rahmah and E. Harlia: Potential of microbial inoculum from buffalo feces in activating lignite coal bed methane. J. Environ. Biol., 41, 650-657 (2020). 


\section{Introduction}

World energy consumption continues to increase along with the growth of human population. The fulfilment of energy demand, so far, comes from fossil fuels which are limited and non-renewable. This is a big problem that needs to be taken seriously by any countries in the world. To secure national sustainable energy security, Indonesia should urgently change to alternative sources of energy. The government of Indonesia promotes exploration for coal bed methane (CBM), in addition to conventional crude oil and natural gas. Coal Bed Methane is an alternative source of energy that can be replaced with fuel oil. CBM is methane trapped in coal pores formed during biogenic and thermogenic process of coal formation or coalification. Utilization of CBM has been carried out by several countries such as the United States, Russia, China, Canada and Australia. Indonesia's CBM reserves are among the largest CBM reserves in the world. In Indonesia, there are 22 blocks type of CBM that have been terminated and 32 blocks of CBM that are still active and being explored but are at the stage of production trials (Kristadi and Dati, 2012).

CBM is a form of natural gas that occurs in coal beds. During coalification process, large amount of gas, mainly methane, are formed biologically in the coal deposits and released during coal extraction. Organic materials are decomposed by anaerobic microbes to form peat. The formation of peat into coal is called coalification. During weathering and coalification, organic materials are decomposed to produce water, $\mathrm{CO}_{2}, \mathrm{CH}_{4}$ and a trace amount of other gases. Methane is trapped in coal seams, especially in lignite and is formed by thermogenic, biogenic, and a mixture of both. (Susilawati et al., 2013). The biogenic process of methane formation occurs through decomposition of organic material contained in coal by methane-producing microbes. There are three stages of biological activity on CBM formation. The first stage is degradation stage of organic material from coal to a simpler material. The second stage is degradation of simple materials into substrates for methanogens. The last stage is methanogenesis, where methane is formed by the activity of anaerobic microbes, particularly methanogens such as Methanolobus sp., Methanobacterium sp. and Candidatus sp. (Guo et al., 2014).

Related to the process of CBM formation by microorganism activity, CBM production can be improved by adding microbial consortium, which is known as Microbially Enhanced Coal Bed Methane (MECBM). Several research have been conducted to enhance anaerobic microorganisms capability in CBM formation (Hamilton et al., 2015; Susilawati et al., 2015; Ritter et al., 2015; Rathi et al., 2015; Wang et al., 2018; Zhi et al., 2018). Some treatments are needed to accelerate the process of secondary biogenic methane, including availability of nutrients for microbes, coal types, hydrological systems, reservoir conditions, microbial types and microbial interactions. There are four categories in the MECBM technique, namely microbial stimulation, microbial augmentation, increasing microbial access and physical distribution, and increasing the bioavailability of coal (Jones et al., 2013). Microbial augmentation in MECBM can be obtained from various sources. One source of microbial consortium that can be used is the microbes present in buffalo feces. Buffalo is a ruminant livestock that relies on microbes as a feed degradation agent and produces volatile fatty acids as a source of energy. The rumen of buffaloes are well adapted to utilize the lignocellulose substrate. This activity could be digested in the rumen system by cellulolytic microbes such as Ruminococcus sp. group, which is more diverse than other ruminants so that potentially being used as a source of microbial consortium (Pandya, 2010; Chanthakhoun et al., 2011; Patel et al., 2014).

Total bacterial content, i.e., cellulolytic bacteria, is higher than cattle (Jadhav et al., 2013). Lignite is one of the low-grade coal types and has the lowest carbon and calorific value compared to other coal types. It is estimated that almost half of the total world coal reserves consist of lignite and sub-bituminous coal. However, lignite has not been widely exploited because it has a lower rank than other coal, both from calories, ease of handling, and storage stability. Lignite, or also called brown coal, is the earliest coal formed in the coal formation process, has carbon content $<69 \%$, and calorific value ranges between 4000 8.300 BTU/pound (Schobert, 2017). One way of increasing the production of CBM from lignite coal is to add microbial populations sourced from buffalo feces. Rumen contains a total of 109 - 1011 cell mll ${ }^{-1}$ bacteria consisting of more than 200 bacterial species (Ekarius, 2010; Weimer, 2019).

Anaerobic microbes break down polymers (carbohydrates, proteins, fats) in the feed into organic acids such as formate, pyruvate, acetate, propionate, butyrate and succinate, and eventually $\mathrm{CH}_{4}$ are formed by rumen methanogen (Chellapandi et al., 2010; Marlina et al., 2018). Some references state that rumen ecology consists of several microbes that produce methane such as Methanobacterium formicicum, Methanobacterium bryantii, Methanobrevibacter ruminantium, Methanobrebobacter smithii, Methanimicrobium mobile, Methanosarcina barkeri and Metnaoculles olentangyi (Puniya et al., 2015; Chellapandi et al., 2018). These microbes form $\mathrm{CH}_{4}$ using $\mathrm{H}_{2}$ to reduce $\mathrm{CO}_{2}$. There are five orders of methanogenic bacteria that play a role in the formation of CBM, namely Methanobacteriales, Methanomocrobiales, Methanosarcinales, Methanococcales and Methanopyrales.

This order has diverse habitats, including digestive tract of animals (Park and Liang, 2016). Microbial addition of bacterial isolates of buffalo feces can affect the indigenous bacterial population of lignite coal. Changes in the population of these bacteria have an impact on the formation of volatile fatty acids that affect the increase of biogas production (Schink, 1997; Grifin et al., 2000; Jones et al., 2010; Strapoc et al., 2011; Krzysztof et al., 2012). During methane formation, VFAs are important indicators because acetogenic bacteria such as Syntrophomonas and Syntrophobacter convert VFAs to acetic acid at acetogenesis 
stage and hydrogen, which is later used by methanogenic to form methane (Chen et al., 2017). Considering the above facts, this research aims to study the ability of microbial consortium from buffalo feces to produce coal bed methane in lignite coal through activation using in-vitro technique.

\section{Materials and Methods}

Materials used at first stage were buffalo feces, Napier grass and concentrate. Buffalo feces and Napier grass were obtained from the adjoining area of Cibinong, Bogor, West Java, Indonesia. The concentrate was obtained from commercial feedmill, CV. Nuansa Baru Indonesia. The materials used at second stage were microbial inoculum obtained from the first stage, coal and growth media. Lignite samples in this experiment were obtained from coal mining located in Simeulue, the west of Aceh Province, Indonesia. Samples of feces, coal, Napier grass and concentrate were analyzed for their chemical properties using proximate analysis. Besides, Van Soest was also used to analyze Acid Detergent Fiber (ADF) and Neutral Detergent Fiber (NDF) in Napier grass (Table 1). Feces samples were taken fresh and squeezed using gauze and then the liquid extracted were poured into a tightly closed flask and taken to the laboratory. Coal samples were cut into small pieces and put into flask.

Preparing Media Number 37, Anaerobic Medium 985, Diluent Solutions: Media Number 37: rumen fluid, $\mathrm{KH}_{2} \mathrm{PO}_{4}, \mathrm{~K}_{2} \mathrm{HPO}_{4}$, $\mathrm{NaCl}, \quad\left(\mathrm{NH}_{4}\right)_{2} \mathrm{SO}_{4}, \mathrm{MgSO}_{4}, \mathrm{CaCl}_{2}, 0.1 \%$ resazurin solution, $\mathrm{NaHCO}_{3}$, Cysteine- $\mathrm{HCl} . \mathrm{H}_{2} \mathrm{O}, \mathrm{Na}_{2} \mathrm{~S}$, distilled water, a mixture of gases $\mathrm{H}_{2}: \mathrm{CO}_{2}=80$ : 20. Media Mineral solution I: $\left(\mathrm{K}_{2} \mathrm{HP}\right)_{4}$ and distilled water. Mineral II solution: $\mathrm{NaCl},\left(\mathrm{NH}_{4}\right)_{2} \mathrm{SO}_{4}, \mathrm{KH}_{2} \mathrm{PO}_{4}$, $\mathrm{CaCl}_{2}, \mathrm{MgSO}_{4} \cdot 7 \mathrm{H}_{2} \mathrm{O}$, distilled water. Anaerobic Medium 985: Mineral solutions I and II, glucose, cellubiose, soluble starch, agar, rumen content extracts, and distilled water were dissolved on a hotplate stirrer and sparged under $\mathrm{N}_{2}$ and $\mathrm{CO}_{2}(80: 20 \mathrm{v} / \mathrm{v})$. Cysteine- $\mathrm{HCl} . \mathrm{H}_{2} \mathrm{O}, \mathrm{Na}_{2} \mathrm{CO}_{3} 8 \%$ solution, and resazurin solution added to the medium. The soluble medium is distributed into a 10 $\mathrm{ml}$ Hungate tube. Autoclaved for 15 minutes at 15 psi pressure $121^{\circ} \mathrm{C}$. Diluent Solutions: Dissolve Mineral solution I, mineral solution II, cysteine- $\mathrm{HCl} . \mathrm{H}_{2} \mathrm{O}, \mathrm{Na}_{2} \mathrm{CO}_{3}$, resazurin, and distilled water. Sparged under $\mathrm{N}_{2}$ and $\mathrm{CO}_{2}(80: 20 \mathrm{v} / \mathrm{v})$ and later autoclaved for 15 minutes at 15 psi pressure- $121^{\circ} \mathrm{C}$. All the media were proposed according to Ogimoto and Imai (1980).

Inoculation: This research was divided into two stages. The first stage was activation using in-vitro methods, and the second stage was of microbial inoculum from buffalo feces into coals and anaerobic medium 985.

Microbial activation: A $100 \mathrm{ml}$ serum bottle was filled with $0.5 \mathrm{~g}$ of feedstuff, McDougall's buffer solution, and feces as a source of microbes. The feedstuff contained concentrate and Napier grass as much as $100 \%$ concentrate, $70 \%$ concentrate: $30 \%$ grass and $30 \%$ concentrate: $70 \%$ grass. The buffer solution was mixed with feces fluid in $33 \mathrm{ml}: 17 \mathrm{ml}$ ratio and then inserted into the serum bottle containing the ration. The buffer solution was prepared by adding $\mathrm{NaHCO}_{3}, \mathrm{Na}_{2} \mathrm{HPO}_{4}, \mathrm{KCl}, \mathrm{NaCl}, \mathrm{MgSO}_{4}, 7 \mathrm{H}_{2} \mathrm{O}, \mathrm{CaCl}_{2}$ and distilled water. The serum bottles were placed in a water bath at $39^{\circ} \mathrm{C}$ for $48 \mathrm{hrs}$, shaken every hour, and gas production was drawn using $50 \mathrm{ml}$ syringe every $2 \mathrm{hrs}$. The fermentation kinetics were portrayed by gas production during $48 \mathrm{hrs}$ of observation as described by odorous and Brooks (1990). Selected inoculum based on gas production during in-vitro activation was added into the enriched medium $(10 \% \mathrm{v} / \mathrm{v})$, incubated at $39^{\circ} \mathrm{C}$ for seven days.

Inoculum preparation: Microbes that have been adapted to the medium were added into $100 \mathrm{ml}$ of enriched medium in serum bottles. In order to maintain anaerobic condition, $\mathrm{N}_{2}$ and $\mathrm{CO}_{2}$ $(80: 20 \mathrm{v} / \mathrm{v})$ were passed into the serum bottle and later incubated for seven days at $36^{\circ} \mathrm{C}$. On day 7 , microbial density per ml was calculated.

Analytical methods: Total Plate Count was used for counting microbes in an anaerobic Hungate tube using roll tube techniques (Ogimoto and Imai, 1980). The sample was incubated at $37^{\circ} \mathrm{C}$ for 30 days and observed bacterial growth on 2, 7 and 28 days. The methane content in Hungate tube was determined by Gas Chromatography as described in Kougias et al. (2014). The concentration of VFAs was measured using titration methods (Mota etal., 2015).

Statistical analyses: Data on VFA production, total biogas and methane production were analyzed using the General Linear Model (GLM) procedure (SAS Inst. Inc., Cary, NC). The difference between means were compared using Duncan New Multiple Range Test (Steel et al., 1997).

\section{Results and Discussion}

Anaerobic bacteria in buffalo feces were under dormant conditions due to contact with environmental oxygen. Therefore, the microbial activation process was required before being used as inoculum. First five hours of gas production were relatively same for all feed types $\left(R_{1}: 100 \%\right.$ Concentrate; $R_{2}$ : Concentrate $70 \%+$ Grass 30\%; $R_{3}$ : Concentrate 30\%+Grass 70\%; $R_{4}$ : Grass $100 \%)$. However, the next hour began to show the difference. The highest gas production for 48 hrs was generated in 100\% concentrate feed type (Fig. 1). Accumulation of gas for $48 \mathrm{hrs}$ on $R_{1}$ showed a significant difference $(P<0.01)$ compared to the result of gas accumulation on $R_{2}$ and $R_{3}$ whereas $R_{2}$ and $R_{3}$ treatment did not show any difference $(P>0.01)$. Use of various types of concentrate: Napier grass ratio as a source of nutrients for microbial activation significantly affected the accumulation of gas production for $48 \mathrm{hrs}(\mathrm{P}<0.01)$.

Use of $R_{1}$ and $R_{2}$ as a nutritional source of microbial buffalo feces showed higher level of material degradation activity compared to $R_{3}$ and $R_{4}$. This condition indicated the rate of gas production per hour for treatment $R_{1}\left(0.038 \mathrm{ml} \mathrm{hr}^{-1}\right)$ and $\left(R_{2} 0.024\right.$ 


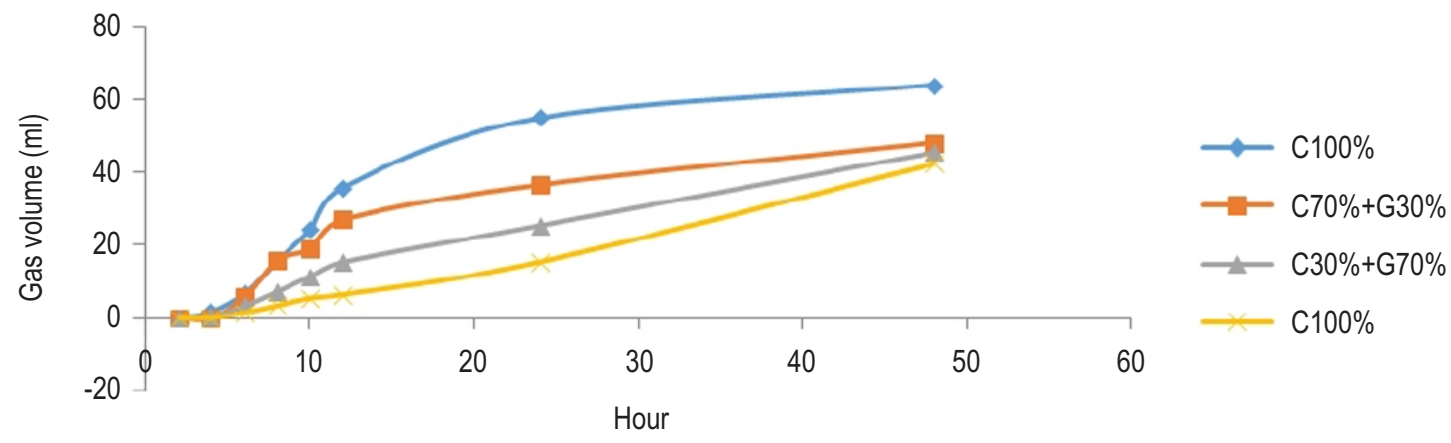

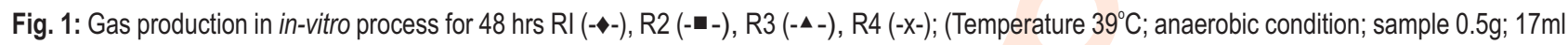
feces fluid and $33 \mathrm{ml}$ buffer solution).

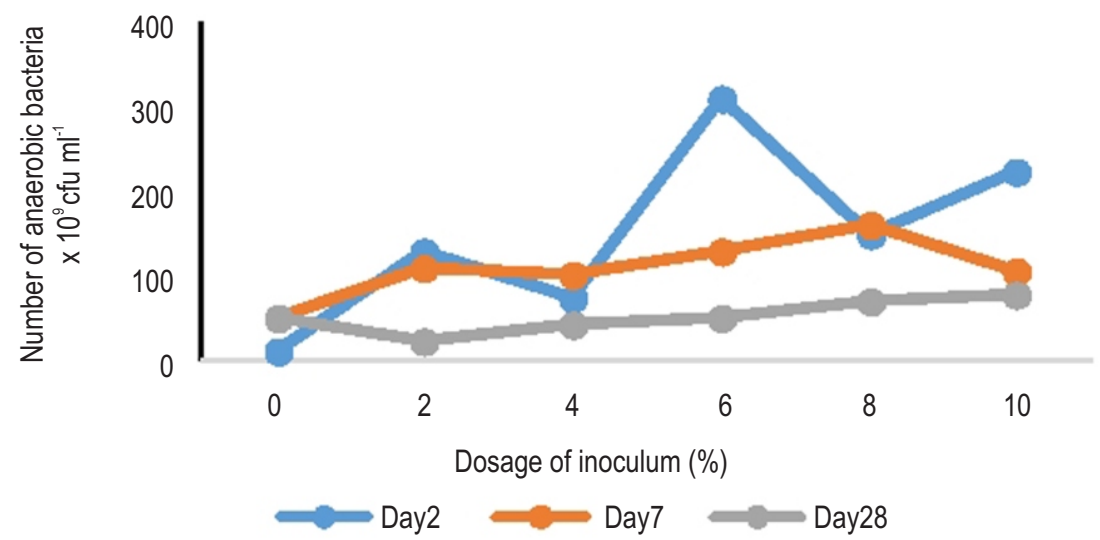

Fig. 2: Number of anaerobic bacteria at various dosages of inoculum during 28 days incubation.

$\mathrm{ml} \mathrm{hr}^{-1}$ ). The value of gas production per hour in $\mathrm{R}_{1}$ and $\mathrm{R}_{2}$ did not show a significant difference between the treatments $(P>0.01)$. Meanwhile, the rate of gas production per hour for both $R_{3}$ and $R_{4}$ were lowest at $0.002 \mathrm{ml} \mathrm{hr}^{-1}$. These results indicated that higher level of grass, correlated with crude fiber content, slower is the process of material degradation; on the contrary, higher the percentage of concentrate, correlated with crude protein content, the process of degradation of materials was faster because crude fiber consist of cellulose, lignin, hemicellulose, acid detergent fiber and neutral detergent fiber that was difficult to digest and could reduce digestibility whereas crude protein could increase digestibility (Fonnesbeck, 1981; De Boever, 2005; Lopez et al., 2019). The rate of gas production per unit time was in accordance with the activity of microorganisms: faster is the gas production, the more active microbes degraded available nutrient sources (Theodorou and Brooks, 1990; Yuan et al., 2019; Shi et al., 2019). Based on this, the microbial activation process was effective while using materials that were easily degradable. $R_{1}$ and $R_{2}$ treatment had a rate of gas production per hour, which was not significantly different $(P>0.01)$ but had a balance of different concentrates and grasses. Concentrate is a feed ingredient that generally contains crude fiber below 18\% and crude protein above 18\% (Badan Standardisasi Nasional, 2009). High levels of crude protein would trigger the growth of proteolytic microbes whereas Napier grass containing high crude fiber triggered more activity of cellulolytic microbes.

Another factor that influenced the anaerobic digestion was $\mathrm{pH}$, among which $\mathrm{pH}$ affected the growth and diversity of microorganisms in anaerobic digestion (Ali et al., 2019). According to Van Soest (1994), the activity of cellulolytic bacteria was inhibited below pH 6.2 and optimum at pH 6.7. As shown in Table 2, the average $\mathrm{pH}$ of each treatment was 6.46 for $\mathrm{R}_{1}, 6.45$ for $R_{2}, 6.527$ for $R_{3}$ and 6.55 for $R_{4}$. The $p H$ value in the activation process showed significant difference between the treatments $(\mathrm{P}>0.01)$. The $\mathrm{pH}$ value, which was not significantly different 
Table 1: Chemical content (\%) and properties of buffalo feces and coals

\begin{tabular}{lllll}
\hline Component & Buffalo feces & Coal & Napier grass & Concentrate \\
\hline Water content & $6.83 \pm 0.03$ & $11.99 \pm 0.73$ & $6.30 \pm 0.04$ & $12,06 \pm 0.14$ \\
Dry matter & $95.17 \pm 0.03$ & $88.30 \pm 0.41$ & $93.70 \pm .04$ & $89.70 \pm 0.15$ \\
Lipid & $2.03 \pm 0.06$ & - & $1.79 \pm 0.07$ & $3.81 \pm 0.15$ \\
Protein & $2.22 \pm 0.36$ & - & $6.42 \pm 0.06$ & $10.63 \pm 0.44$ \\
Total nitrogen & $9.94 \pm 0.36$ & $3.54 \pm 0.1$ & - & - \\
Ash & $27.47 \pm 0.33$ & $15.60 \pm 1.43$ & $7.67 \pm 1.31$ & $5.54 \pm 0.20$ \\
Fiber & $32.03 \pm 0.29$ & - & $32.64 \pm 0.04$ & $15.99 \pm 0.09$ \\
Phosphorus & $0.61 \pm 0.03$ & - & $0.21 \pm 0.01$ & $4.44 \pm 0.05$ \\
Arginine & & & & $0.95 \pm 0.01$ \\
& $0.49 \pm 0.01$ & - & $0.07 \pm 0.01$ & $0.16 \pm 0.01$ \\
Cystine & $0.42 \pm 0.01$ & - & $0.58 \pm 0.02$ & $0.46 \pm 0.01$ \\
Glycine & $0.73 \pm 0.01$ & - & $1.69 \pm 0.03$ & $0.49 \pm 0.06$ \\
Lysine & $2.67 \pm 0.01$ & - & $67.68 \pm 0.20$ & $68.83 \pm 0.15$ \\
Total digestible nutrient & - & - & $54.29 \pm 1.35$ & $18.78 \pm 0.05$ \\
Acidic detergent fiber & $28,71 \pm 0.05$ & - & $71.14 \pm 1.08$ & $35.90 \pm 0.98$ \\
Neutral detergent fiber & $42.55 \pm 0.22$ & - & &
\end{tabular}

Table 2: Gas production, rate of gas production and $\mathrm{pH}$ in anaerobic bacteria activation under various treatments

\begin{tabular}{llll}
\hline Treatments & Gas production $(\mathrm{ml})$ in $\mathbf{4 8} \mathrm{hrs}$ & Rate of gas production $\left(\mathrm{ml} \mathrm{hr}^{-1}\right)$ & $\mathrm{pH}$ \\
\hline $\mathrm{R}_{1}$ & $65.2^{\mathrm{b}} \pm 1.041$ & $0.038^{\mathrm{b}} \pm 0.003$ & $6.46^{\mathrm{a}} \pm 0.021$ \\
$\mathrm{R}_{2}$ & $46.5^{\mathrm{a}} \pm 1.803$ & $0.024^{\mathrm{b}} \pm 0.010$ & $6.45^{\mathrm{a}} \pm 0.055$ \\
$\mathrm{R}_{3}$ & $45.0^{\mathrm{a}} \pm 1.500$ & $0.002^{\mathrm{a}} \pm 0.001$ & $6.53^{\mathrm{a}} \pm 0.093$ \\
$\mathrm{R}_{4}$ & $42.2^{\mathrm{a}} \pm 1.105$ & $0.002^{\mathrm{a}} \pm 0.001$ & $6.55^{\mathrm{a}} \pm 0.082$ \\
\hline
\end{tabular}

$R_{1}=$ concentrate $100 \% ; R_{2}=$ concentrate $70 \%+$ Napier grass $30 \% ; R_{3}=$ concentrate $30 \%+$ Napier grass $70 \% ; R_{4}=$ Napier grass $100 \%$; ${ }^{a, b}$ denote significance $(\mathrm{P}<0.05)$; at $39^{\circ} \mathrm{C}$ and anaerobic condition; each treatment consisted of $0.5 \mathrm{~g}$ sample, $17 \mathrm{ml}$ feces fluid and $33 \mathrm{ml}$ buffer solution

Table 3: VFA production, total gas and methane production on various dosage of inoculum during 28 days of observation

\begin{tabular}{|c|c|c|c|c|c|c|c|c|c|}
\hline \multirow{2}{*}{$\begin{array}{l}\text { Inoculum } \\
(\%)\end{array}$} & \multicolumn{3}{|c|}{ Days 2} & \multicolumn{3}{|c|}{ Days 7} & \multicolumn{3}{|c|}{ Days 28} \\
\hline & $\begin{array}{l}\text { VFA }^{a b} \\
(m M)\end{array}$ & $\begin{array}{l}\text { Total } \\
\text { gas }^{\text {a }}(\mathrm{ml})\end{array}$ & $\mathrm{CH}_{4}^{\mathrm{a}}(\%)$ & $\begin{array}{l}\text { VFA }^{\mathrm{a}} \\
(\mathrm{mM})\end{array}$ & $\begin{array}{l}\text { Total } \\
\text { gas }^{\text {b }}(\mathrm{ml})\end{array}$ & $\mathrm{CH}_{4}^{\mathrm{b}}(\%)$ & $\begin{array}{l}\text { VFA }^{\mathrm{b}} \\
(\mathrm{mM})\end{array}$ & $\begin{array}{l}\text { Total gas } \\
(\mathrm{ml})\end{array}$ & $\begin{array}{l}\mathrm{CH}_{4}{ }^{\mathrm{c}} \\
(\%)\end{array}$ \\
\hline 0 & $125.33 \pm 15.21$ & $10.5 \pm 1.08$ & $0.031 \pm 0.002$ & $120.00 \pm 9.76$ & $10.76 \pm 0.78$ & $0.130 \pm 0.01$ & $115.00 \pm 8.71$ & $15.76 \pm 0.52$ & $0.108 \pm 0.06$ \\
\hline 2 & $135.67 \pm 17.20$ & $3.00 \pm 0.78$ & $0.050 \pm 0.003$ & $130.67 \pm 11.82$ & $6.69 \pm 1.12$ & $1.472 \pm 0.02$ & $135.33 \pm 7.23$ & $96.20 \pm 0.48$ & $8.538 \pm 0.38$ \\
\hline 4 & $141.33 \pm 14.92$ & $9.00 \pm 0.95$ & $0.057 \pm 0.003$ & $141.67 \pm 11.50$ & $16.08 \pm 3.75$ & $0.565 \pm 0.02$ & $139.00 \pm 5.21$ & $113.11 \pm 1.01$ & $16.369 \pm 1.79$ \\
\hline 6 & $162.67 \pm 17.21$ & $6.64 \pm 0.36$ & $0.061 \pm 0.002$ & $164.00 \pm 11.61$ & $13.25 \pm 2.05$ & $0.665 \pm 0.08$ & $171.67 \pm 5.72$ & $107.95 \pm 1.01$ & $9.252 \pm 1.86$ \\
\hline 8 & $130.67 \pm 17.22$ & $8.14 \pm 0.75$ & $0.058 \pm 0.001$ & $25.33 \pm 8.25$ & $14.49 \pm 2.05$ & $2.327 \pm 0.10$ & $140.33 \pm 6.82$ & $103.40 \pm 0.62$ & $16.425 \pm 1.82$ \\
\hline 10 & $105.33 \pm 11.71$ & $6.64 \pm 0.75$ & $0.068 \pm 0.002$ & $104.33 \pm 9.22$ & $13.32 \pm 2.37$ & $1.282 \pm 0.09$ & $123.67 \pm 5.72$ & $128.61 \pm 1.02$ & $9.660 \pm 0.98$ \\
\hline
\end{tabular}

a,ba ab,c denote significance $(P<0.05)$

between treatments, indicated that the $\mathrm{pH}$ was not correlated to the difference in the rate of gas production per hour. Based on the average values of all the $\mathrm{pH}$, all the treatments could provide a $\mathrm{pH}$ value that supported the growth and development of microorganisms. The second stage was conducted by utilizing the inoculum obtained from first stage of research, namely through microbial activation which was fed with $70 \%$ concentrate and $30 \%$ grass. After adaptation for seven days, the amount of inoculum obtained reached $1.33 \times 10^{11} \mathrm{cfu} . \mathrm{ml}^{-1}$ on average. VFA resulted due to degradation of complex organic materials by microorganisms into organic acids such as acetate, butyric, propionate and valerate (McDonald, 2010; Orem et al., 2010; Chen et al., 2017). VFAs production was significantly influenced by incubation time and inoculum doses $(P<0.05)$, but there was no interaction between the two treatments $(P>0.05)$. The highest volatile fatty acids (Table 3 ) was produced on day 28 (141.27 $\mathrm{mM})$, followed by day 2 (135.13 mM) and day $7(133.2 \mathrm{mM})$. There was no accumulation of total VFA production over time of 
incubation. This indicates that the VFAs produced is used by methanogens to form methane (Seadi, 2014). VFAs such as propionate and butyrate are utilized by acetogenic bacteria such as Syntrophomonas or Syntrophobacter to form acetate and hydrogen (Schink, 1997). VFAs with short carbon chains of acetate and formic acid are utilized by methanogens to form methane from $\mathrm{CO}_{2}$ reduction using $\mathrm{H}_{2}$ (Krzysztof, 2012).

The addition of $6 \%$ inoculum resulted in the highest yield of VFAs, while the lowest VFAs was obtained by adding $10 \%$ inoculum. VFAs production is directly proportional to the activity of microorganisms in degrading the substrate. The phenomenon of high doses of inoculum, that leads to low concentrations of VFAs, relates to the population and the ability of microbes to degrade organic matter contained in coal. Majority of microbial population causes substrate competition, whereas low microbial population cause less substrate degradation. Competition between microorganisms due to population density leads to dominance of one species (Hibbing et al., 2010; Stubbendieck and Straight, 2016). Dominance of one type of microbe may lead to low production of VFAs. VFA is formed by the activity and the relationship between microbial species through 2 stages on. At first stage organic matter is degraded into simple sugars by the enzymes produced by microbes. At the second stage, pyruvic acid is converted into VFA through the microbial intracellular metabolism process. VFA results are influenced by the types of microorganisms that play a role in degrading pyruvic acid into acetate, butyric or propionate (Song et al., 2018).

There was no relationship between VFAs production and number of anaerobic bacteria (Fig.2). The number of microbes was lowest on day 28 at $6 \%$ inoculum, while VFAs production was highest (Table 2). Generally, microbial count and VFA production were inversely proportional. However, on the $2^{\text {nd }}$ day of incubation, high number of microbes aligned with high concentrations of VFAs were produced. Overall, total VFA production in this study was $115.0-171.7 \mathrm{mM}$. Methane is a natural gas formed by anaerobic fermentation of organic matter (Li et al., 2015; Yang et al., 2019). There was no interaction between the incubation time and inoculum doses on biogas and methane production, however, the production of biogas and methane was significantly influenced by incubation time and doses of inoculum. The process of biogas formation occurs gradually over time (Table 2). Biogas derived from organic matter contains $60-70 \% \quad \mathrm{CH}_{4}, 30-40 \% \quad \mathrm{CO}_{2}$ and $<1 \% \quad \mathrm{~N}_{2}$. However, coal is not an ideal substrate for bacterial growth (Kabe et al., 2004). Therefore, efforts to synergize certain types of bacterial species as inoculums are necessary.

Based on the process, coal bed methane is produced through biogenic and thermogenic process. Biogenic processes rely on the role of microbes in methane formation. Aerobic microbes utilize remaining oxygen in plant residues and sediments. After oxygen is depleted, the anaerobic microbe works and produces methane by converting $\mathrm{CO}_{2}$ and degrading organic content in coal (Robbins et al., 2016; Zheng et al., 2017).
On comparing biogas production with the addition of inoculum versus without the addition of inoculum suggests that the addition of microbial inoculum from buffalo feces can increase biogas production (Table 2) with methane content of $16.43 \%$. The addition of selected bacterial and methanogen consortiums can increase methane production (Zhang et al., 2019; Ali et al., 2019) by $0.1 \mu \mathrm{mol}$ methane day $\mathrm{g}^{-1}$ coal in the first 50 days of incubation period, and $3 \mu \mathrm{mol}$ methane day ${ }^{-1} \mathrm{~g}^{-1}$ coal during 50-70 days of incubation period. The effectiveness of biogas formation is influenced by factors such as anaerobic conditions, temperature, $\mathrm{pH}$, substrate content and VFA concentration.

VFA is an essential component in biogas formation as acetogenesis and methanogenesis converts long chain VFA into acetate, which is further fermented into methane and $\mathrm{CO}_{2}$ by methanogens (Huang et al., 2018; Yuan et al., 2019). Methanogens are an important factor that influences the process of biogas formation (Andre et al., 2016; Mohd Yasin et al., 2017; Xu et al., 2019). Microbial activation using a modified in-vitro technique is required to obtain a high number of microbial inoculums. Addition of microbial inoculums from buffalo feces can increase coal bed methane production. However, it is necessary to add the right dosage of inoculum so that competition over substrate can be avoided and optimal coal bed methane can be produced.

\section{Acknowledgment}

This work is financially supported by Rector of Universitas Padjadjaran, Bandung, under the Academic Leadership Grant (ALG) Program, Contract No. 855/UN6.3.1/PL/2017.

\section{References}

Ali, S., B. Hua, J. J. Huang, R.L. Droste, Q. Zhou, W. Zhao and L.Chen : Effect of different initial low pH conditions on biogás production, composition, and shift in the acetilastic methanogenic population. Bioresour. Technol., 289, 1-6 (2019)

Ali, S.S., R. Al-Tohamy, A. Manni, F. C. Luz, T. Elsamahy and J. Sun : Enhanced digestion of bio-pretreated sawdust using a novel bacterial consortium: Microbial community structure and methaneproducing pathways. Fuel, 254, 1-15(2019).

Andre, L., M. Ndiaye, M. Pernier, O. Lespinard, A. Pauss, E. Lamy and T. Ribeiro: Methane production improvement by modulation of solid phase immersion in dry batch anaerobic digestion process: Dynamic of methanogen populations. Bioresour. Technol., 207, 353-360 (2016).

Badan Standardisasi Nasional : Pakan Konsentrat Sapi Perah, Standar Nasional Indonesia, SNI 3148.1:2009, p.4 (2009).

Chanthakhoun, V., M. Wanapat, C. Wachirapakorn and S. Wanapat : Effect of legume (Phaseolus calcaratus) hay supplementation on rumen microorganisms, fermentation and nutrient digestibility in swamp buffalo. Livestock Sci., 140, 17-23 (2011).

Chellapandi, P., D. Prabaharan and L. Uma: Evaluation of methanogenic activity of biogas plant slurry for monitoring co-digestion of ossein factory wastes and cyanobacterial biomass. App. Biochem. Biotech., 162, 524-535 (2010).

Chellapandi, P., M. Bharathi, C. Sangavai and R. Prathiviraj : Methanobacterium formicicum as a target rumen methanogen for 
the development of new methane mitigation interventions: A review. Vet. Anim. Sci., 6, 86-94 (2018).

Chen, Y., X. Jiang, K.Xiao, N. Shen, R.J. Zeng and Y. Zhou : Enhanced volatile fatty acids (VFAs) production in a thermophilic fermenter with stepwise $\mathrm{pH}$ increase-Investigation on dissolved organic matter transformation and microbial community shif. Water Res. 112, 261-268 (2017).

De Boever, J.L., J.M. Aerts, J.M. Vanacker and De Brabander: Evaluation of the nutritive value of maize silages using a gas production technique. Anim. Feed Sci. Technol., 123-124, 255-265 (2005).

Ekarius, C.: Small-Scale livestock farming: A grass-based approach for health, sustainability, and profit. Storey Publishing, 192 (2010).

Fonnesback, P.V, J.L. Christiansen and L.E. Harris : Factors affecting digestibility of nutrients by sheep. J. Anim. Sci., 52, 363-376 (1981).

Guo, H., Z. Yu, I.P. Thomson and H. Zhang: A contribution of hydrogenotrophic methanogenesis to the biogenic coal bed methane reserves of southern Qinshui basin, China. App. Microbiol. Biotechnol., 98, 9083-9093 (2014).

Griffin M.E., K.D. McMahon, R.I. Mackie and L. Raskin : Metanogenic population dynamics during start-up of anaerobic digesters treating municipal solid waste and biosolids. Biotechnol. Eng., 57, 342-355 (2000).

Hamilton, S.K., S.D. Golding, K.A. Baublys and J.S. Esterle : Conceptual exploration targeting for microbially enhanced coal bed methane (MECoM) in the Wallon Subgroup, Eastern Surat Basin, Australia. Int. J. Coal Geol., 138, 68-82 (2015).

Hibbing, M.E., C. Fuqua, M.R. Parsek and S. Peterson: Bacterial competition: Surviving and thriving in the microbial jungle. Nat. Rev. Microbiol., 8, 15-25 (2010).

Huang, L., Z. Chen, D. Xiong, Q. Wen and Y. Ji : Oriented acidification of wasted activated sludge (WAS) focused on odd-carbon volatile fatty acid (VFA): Regulation strategy and microbial community dynamics. WaterRes., 142, 256-266 (2018).

Jadhav, S.K., G.B. Deskmukh, S. Sathapathy, S.R. Lende, G.G. Sewatkar and S.K. Joshi: Fiber degradation in buffalo-an innovative approach. IOSR-JAVS. 2, 25-27 (2013)

Jones, E.J.P., M.A. Voytek, M.D. Corum and W.H. Orem: Stimulation of methane generation from nonproductive coal by addition of nutrients or a microbial consortium. App. Environ. Microb., 76, 7013-7022 (2010).

Jones, E.J.P., S.H. Harris, E.P. Barnhart, W.H. Orem, A.C. Clark, M.D. Corum, J.D. Kirshtein, M.S. Varonka and M.A. Voytek: The effect of coal bed dewatering and partial oxidation on biogenic methane potential. Int. J. Coal Geol., 115, 54-63 (2013).

Kabe, T., A. Ishihara, E.W. Qian, I.P. Sutrisna and Y. Kabe : Coal and Coal-Related Compounds: Structures, Reactivity, and Catalytic reactions (Studies in Surface Science and Catalysis). $1^{\text {st }}$ Edn., Vol. 179, Elsevier Sci. Technol. Amsterdam, pp. 269-362 (2004).

Kougias, P.G., K. Boe, P. Tsapekos and I. Angelidaki: Foam suppression in overloaded manure-based biogas reactors using antifoaming agents. Bioresour. Technol., 153, 198-205(2014).

Kristadi, H.J. and D.W. Dati: Coal Bed Methane, New Energy foe People. Research and Development Center of Oil and Gas Technology. Research and development Agency of Energy and Mineral Resources. Ministry of Energy and Mineral Resources Republic of Indonesia (2012)

Krzysztof, Z. and F. Magdalena: Methane fermentation process as anaerobic digestion of biomass: Transformations, stages, and microorganism. African J. Biotech., 11, 4127-4139 (2012).

Li, Q., Y-Y. Li, W. Qiao, X. Wang and K. Takayanagi: Sulfate addition as an effective methode to improve methane fermentation performance and propionate degradation in thermophilic anaerobic co- digestion of coffee grounds, milk and waste activated sludge with AnMBR. Bioresour. Technol., 185, 308-315(2015).

Lopez, D.I.L.G., J.A.L-Correa, M.E.S-Pardo, M.A.D-Crespo, A.M.THuerta, A.E.R-Salazar and V.N.O-Guzman: Production of dietary fibers from sugarcane bagasse and sugarcane tops using microwave-assisted alkaline treatments. Indust. Crops Products, 135, 159-169 (2019).

Marlina, E.T., T.B.A. Kurnani, Y.A. Hidayati, K.N. Rahmah and E. Harlia: The potential of various livestock waste as sources of methanogenic bacteria. J. Pow. Tech Adv. Func. Mater., 1, 19-23 (2018)

McDonald, P., R.A. Edwards, J.F.D. Greenhalgh, C.A. Morgan, L.A. Sinclair and R.G. Wilkinson: Animal Nutrition. $7^{\text {th }}$. Edn., Pearson Press (2010)

Mota, V.T., F.S. Santos, T.A. Araujo and M.C.S. Amaral: Evaluation of titration methods for volatile fatty acids measurement: Effect of bicarbonate interference and feasibility for monitoring of anaerobic reactors. Water Pract. Technol., 10, 486-495 (2015).

Mohd Yasin, N.H., A. Ikegami, T.K. Wood, C-P. Yu and T. Haruyama: Oceans as bioenergy pools for methane production using activated methanogens in waste sewage sludge. App. Energy, 202, 399-407 (2017).

Ogimoto, K. and S. Imai : Atlas of Rumen Microbiology. Tokyo, Japan Scientific Societies Press (1980).

Orem, W.H., M.A. Voytek, E.J.P. Jones, H.E. Lerch, A.L. Bates, M.D. Corum, P.D. Warwick and A.C. Clark: Organic intermediates in the anaerobic biodegradation of coal to methane under laboratory condition. Org. Geochem., 41, 997-1000 (2010).

Pandya, P.R., K.M. Singh, S. Parnekar, A.K. Tripathi, H.H. Mehta, D.N. Rank, R.K. Kothari and C.G. Joshi: Bacterial diversity in the rumen of indian Surti Buffalo (Bubalus bubalis) assessed by 16S rDNA Analysis. J. Appl. Genet., 51, 395-402 (2010).

Park, S.Y. and Y. Liang : Biogenic methane production from coal: A review on recent research and development on microbially enhanced coalbed methane (MECBM). Fuel, 166, 258-267 (2016).

Pattel, D.D., A.K. Patel, N.R. Palmar, T. M. Shah, J.B. Patel, P.R. Pandya and C.G. Joshi : Microbial and carbohydrate active enzyme profile of buffalo rumen metagenome and their alteration in response to varian in the diet. Gene, 545, 88-94 (2014)

Puniya, A.K., A.Z.M. Salem, S. Kumar, S.S. Dagar, G.W. Griffith, M. Puniya, S.R. Ravella, N. Kumar, T. Dhewa and R. Kumar: Role of live microbial feed supplements with reference to anaerobic fungi in ruminant productivity:Areview. J. Integ. Agric., 14, 550-560 (2015).

Rathi, R., A. Priya, M. Vohra, M. Lavania, B. Lal and P.M. Sarma: Development of a microbial process for methane generation from bituminous coal at thermophilic conditions. Int. J. Coal Geol., 147148, 25-34 (2015).

Ritter, D., D. Vinson, E. Barnhart, D.M. Akob, M.W. Fields, Al.B. Cunningham, W. Orem and J.C. Mcintosh: Enhanced microbial coalbed methane generation: A review of research, commercial activity, and remaining challenges. Int. J. Coal Geol., 146, 28-41 (2015).

Robbins, S.J., P.N. Evans, J.S. Esterle, S.D. Golding and G.W. Tyson: The effect of coal rank on biogenic methane potential and microbial composition. Int. J. Coal Geol., 154-155, 205-212 (2016).

Schobert, H.: Introduction to low-rank coals: Types, resources and current utilization. Low-Rank Coals for Power Generation, Fuel and Chemical Production. Woodhead Publishing, pp. 3-21 (2017).

Song, C., M. Li, H. Qi, Y. Zhang, D. Liu, X. Xia, H. Pan and B. Xi: Impact of anti-acidification microbial consortium on carbohydrate metabolism of key microbes during food waste composting. Bioresour. Technol., 259, 1-9 (2018). 
Schink, B.: Energetics of syntrophic cooperation in metanogenic degradation. Microb. Mol. Biol. Rev., 61, 262-280 (1997).

Seadi, T.A, D. Rutz, H. Prassl, M. Kottner, T. Finsterwalder, S. Volk and R. Janssen: Handbook of Biogas. University of Southern Denmark Esbjerg, Niels Bohrs Vej 9-10, DK-6700 Esbjerg, Denmark (2014).

Shi, X., J. Zuo, M. Zhang, Y. Wang, H. Yu and B. Li: Enhanced biogas production and in situ ammonia recovery from food waste using a gas-membrane absorption anaerobic reactor. Bioresour. Technol., 292, 1-8(2019)

Steel, R.G.D., J.H. Torrie and D.A. Dicky: Principles and Procedures of Statistics, A Biometrical Approach. $3^{\text {rd }}$ Edn., McGraw Hill Inc. Book Co., New York, pp. 352-358 (1997).

Strapoć, D., M. Mastalerz, K. Dawson, J. Macalady, A.V. Callaghan, B. Wawrik, C. Turich and M. Ashby: Biogeochemistry of microbial coalbed methane. Annu. Rev. Earth Planet Sci., 39, 617-656 (2011).

Stubbendieck, R.M. and P. Straight: Multifaceted of bacterial competition. J. Bacteriol., American Society Microbiology, 198, 2145-2155 (2016).

Susilawati, R., S.I. Papendick, P.C. Gilcrease, J.S. Esterle, S.D. Golding and T.E. Mares: Preliminary investigation of biogenic gas production in Indonesia low-rank coals and implications for a renewable energy source. J. Asian Earth Sci., 77, 234-242 (2013).

Susilawati, R., J.S. Esterle, S.D. Golding and T.E. Mares: Microbial methane potential for the south Sumatra Basin Coal: Formation water screening and coal substrate bioavailability. Energy Proc., 65, 282-291 (2015).

Theodorou, M.K. and A.E. Brooks: Evaluation of a new procedure for estimating the fermentation kinetics of tropical feeds. The Natural Res., Institute, Ctatham (1990).
Van Soest, P.J.: Nutriitional Ecology of the Ruminant. $2^{\text {nd }}$ Edn., Cornell University Press, Ithaca, p. 476 (1994).

Wang, A., P. Shao, F. Lan and H. Jin: Organic chemicals in coal available to microbes to produce biogenic coalbed methane: A review of current knowledge. J. Nat. Gas Sci. Eng., 60, 40-48 (2018).

Weimer, P.J.: Microbial Ecology of the Rumen. Ency. Microbiol., $4^{\text {th }}$ Edn., Elsevier Inc., pp. 125-131 (2019).

Xu, R., S. Xu, A.P. Florentino, L. Zhang, Z. Yang and Y. Liu: Enhancing blackwater methane production by enriching hydrogenotrophic methanogens through hydrogen supplementation. Bioresour. Technol., 278, 481-485 (2019).

Yang, F., L. Bai, P. Li, Q. Li, L. Luo and W. Li: Improved methane production and sulfate removal by anaerobic co-digestion corn stalk and levulinic acid wastewater pretreated by calcium hydroxide. Sci. Total Environ., 691, 499-505 (2019).

Yuan, Y., X. Hu, H. Chen, Y. Zhou, Y. Zhou and D. Wang : Advances in enhanced volatile fatty acid production from anaerobic fermentation of waste activated sludge. Sci. Total Environ., 694, 133741, 1-8 (2019)

Zhi, S., D. Elsworth, J. Wang, Q. Gan and S. Liu: Hydraulic fracturing for improved nutrient delivery in microbially-enhanced coalbed methane (MECBM) production. J. Nat. Gas Sci. Eng., 60, 294-311 (2018).

Zhang, F., W. Zhang, D-K. Qjan, K. Dai, M.C.M. van Loosdrecht and R.J. Zeng: Synergetic alginate conversion by a microbial consortium of hydrolytic bacteria and methanogens. Water Research, 163, 114892: 1-9 (2019).

Zheng, H., T. Chen, V. Rudolf and S.D. Golding: Biogenic methane production from Bowen Basin coal waste materials. Int. J. Coal Geol., 169, 22-27 (2017). 